\title{
НАЦІОНАЛЬНА НЕВЕРБАЛІКА В ПОЕТИЧНОМУ МОВЛЕННІ СТЕПАНА РУДАНСЬКОГО
}

\author{
ТЕТЯНА ОСІПОВА \\ Харківський національний педагогічний університет імені Г. С. Сковороди, \\ Харків - Україна

\section{NARODOWA SPECYFIKA NIEWERBALNOŚCI W POETYCKIEJ STYLISTYCE STEPANA RUDANSKIEGO}

\author{
TETIANA OSIPOVA \\ Charkowski Narodowy Uniwersytet Pedagogiczny im. H. Skoworody, Charków — Ukraina
}

STRESZCZENIE. W artykule podjęto próbę omówienia kunsztu poetyckiego S. Rudanskiego w operowaniu środkami niewerbalnymi, które wykorzystane zostały w humoreskach poety. Sposoby omówienia niewerbalności w dyskursie artystycznym służą do realizacji szeregu pragmatycznych funkcji: przy ich pomocy wyrażana jest specyfika narodowego charakteru Ukraińców, tj.: ukraiński kordocentryzm, pogłębiona emocjonalność oraz ekspresyjność, pragnienie stworzenie języka o większej dynamice, ,żywotności”, intymności.

\section{NATIONALLY SPECIFIED NON-VERBAL MEANS IN STEPAN RUDANSKIY'S POETIC SPEECH}

\section{TETIANA OSIPOVA \\ H. S. Skovoroda Kharkiv National Pedagogical University, Kharkiv — Ukraine}

ABSTRACT. The article deals with Stepan Rudanskiy's mastery of modeling non-verbal means, which are widely spread in the poet's songs. The means of verbalizing the non-verbal in the artistic discourse serve the realization of a set of pragmatic functions: the representation of the Ukrainians' national character specificity, for example, cordocentricity, high emotivity and expressiveness, a desire to make the speech more dynamic and live, more intimate.

ууасні підходи лінгвістичних досліджень зумовлюють інтерес до мови
як дискурсивної категорії, тому лінгвісти вдаються до прагматичного
аналізу ідіостилю особистості, визначення мовної і комунікативної ком-
петенції загалом, використовуючи як дослідницький матеріал авторський ху-
дожній або публіцистичний тексти (дискурси), промови або виступи тощо, зва-
жаючи на характер метамовної рефлексії, що є не стільки „пасивною”, такою,
що фіксує та коментує відповідні явища мови й мовлення, скільки ,активною”
— на базі власних уявлень мовець вибудовує мовну тканину тексту, моделює мов-
ну поведінку персонажів відповідного художнього твору, конструює їхні репліки
та невербальні дії, відбирає метамовну лексику для авторських ремарок і т. ін. ${ }^{1}$
Фахівці зазначають, що „антропоцентрична парадигма в дослідженні мови,
що передбачає розгляд діяльності людини у всіх їі аспектах, інтерес до кому-

${ }^{1}$ Див. про це: Т. Ф. Осіпова, Вербалізація паралінгвальних засобів комунікації у творах T. Г. Шевченка, [в:] „Лінгвістичні дослідження”, Зб. наук. праць Харк. нац. пед. у-ту ім. Г. С. Сковороди, за ред проф. Л. А. Лисиченко, 2013, вип. 35, с. 215-225. 
нікації у всіх іiі проявах створили умови для залучення невербальних компонентів комунікації до кола інтересів мовознавчих розвідок <..> Комунікативні здібності мовця виявляються передусім на вербальному рівні, але комунікація - це складний комплекс, основними принципами якого залишаються багатоаспектне сприйняття змісту повідомлення через стосунки мовців, транзакційний та нелінійний характер"2.

За цим принципом художній текст розглядаємо як естетичний феномен iз притаманним йому безпосереднім вираженням відповідних явищ дійсності. Художнє мовлення - це своєрідно спроектоване людиною втілення естетичного в специфічному матеріалі, яким, по суті, є динамічна система мовних засобів.

Поняття „живе мовлення” визначається передусім такими параметрами, як динамічність, усно- й писемно виражений спонтанний модус, рухомість, креативність ${ }^{3}$.

Живе мовлення - це реалізація повсякденної комунікації, тому воно безпосередньо пов'язане 3 поняттям „комунікативна компетенція”, що репрезентує мовне чуття - систему неусвідомлених оцінок, які відображають мовні ідеали, і мовний смак - систему установок людини щодо мови й мовлення на певному етапі їхнього розвитку 5 .

У ,живому мовленні” послідовно зреалізовані принципи економії й емфази, меліоративності й пейоративності, евфемізації й табуювання, афективності й ефективності, тобто відбиті постулати Грайса і Ліча, що дає змогу „описувати комунікативні контакти як аксіологічно марковані вербальні простори”.

В українській мовній і культурній спадщині С. Руданський відомий і як поет-песиміст у ліричних поезіях, повних розпачливого смутку, і як „сміхотун” (так назвав його С. Єфремов), завдяки його веселим співомовкам, у яких автор віддзеркалює специфіку етнічного спілкування.

Лінгвопоетичний метод дослідження комплексу лінгвістичних засобів, які використовує автор у конкретному творі, дає змогу простежити їхню прагматику в певному конкретному тексті словесно-художньої творчості, оскільки мова $€$ „гнучким засобом знакової репрезентації досвіду й комунікативної взаємодії між членами соціокультурного суспільства в кожній конкретній ситуації”.

Згідно з гіпотезою Сепіра-Уорфа в мові відображена культура народу. Р. Ладо писав, що „культура - структурована система моделювання поведінки людини" . Мова конкретного суспільства є складником його культури, а лексичні розмежування зазвичай відображають важливі точки зору цієї культури, властивості об'єктів, видів діяльності, установок того суспільства, у якому функціонує мова.

2 Л. В. Солощук, Взаємодія вербальних і невербальних компонентів комунікації у сучасному англомовному дискурсі, Автореф. дис. д-ра філол. наук, Київ 2009.

3 Див. про це: Т. А. Космеда, Статус поняття „жсие мовлення” в парадигмі сучасного мовознавства і традиційної лінгвістики, [в:] „Лінгвістичні дослідження”, Зб. наук. праць Харків. нац. пед. ун-ту ім. Г. С. Сковороди, за ред. проф. Л. А. Лисиченко, Харків 2014, вип. 3, с. $179-184$.

4 Т. Космеда, Комунікативна компетенція I. Франка: міжкультурні, інтерперсональні, риторичні виміри, Львів 2006.

${ }_{5}^{5}$ В. И. Карасик, Речевое поведение и типы языковых личностей, [в:] „Массовая культура на рубеже XX - XX веков: Человек и его дискурс”, Сбор. науч. труд., под ред. Ю. А. Сорокина, М. Р. Желтухиной, Москва 2003, с. 24-45.

${ }^{6}$ Ю. А. Сорокин, Человек говорящий в его модусах и отношениях (обзор-дискуссия), [в:] „Массовая культура на рубеже XX - XX веков: Человек и его дискурс ”, Сбор. науч. труд., под ред. Ю. А. Сорокина, М. Р. Желтухиной, Москва 2003, с. 10.

${ }^{7}$ И. П. Сусов, Лингвистическая прагматика, Москва 2006, с. 25. 
Як зазначають фахівці, „невербальний компонент $є$ трирівневим утворенням, у якому відображено його універсальність, етноспецифічність та індивідуально означений характер. Універсальність невербальних компонентів забезпечує їхню доступність та зрозумілість практично для кожного мовця, незалежно від його комунікативного досвіду спілкування або комунікативної компетенції. Етноспецифічність, навпаки, звужує доступність невербаліки для комунікантів, які належать до інших лінгвоспільнот. Індивідуальна означеність у структурі невербаліки вимагає додаткових знань про співбесідника для адекватного декодування змісту"8.

У І. Франка є „незакінчена, на жаль, праця, присвячена паралінгвістичним засобам”, зокрема жесту „кивок головою”, специфічність сприйняття якого проілюстрована співомовкою С. Руданського „Рабин і запорожець”, де описана ситуація девіаційного характеру, що виникла між рабином і запорожцем під час їхньої розмови, яка здійснювалася з актуалізацією невербальних засобів комунікації.

Однак, крім Івана Франка, жоден із дослідників творчого доробку С. Руданського не зауважив активності поета щодо омовлення невербаліки, яка супроводжує живе мовлення.

Невербальна поведінка — це вагомий засіб комунікації, основна мета якої - орієнтація і вплив. Як лінгвістичний знак, невербальна поведінка містить інформацію, означає реальні об'єкти, здійснює цілеспрямований вплив на інших людей.

Теоретичні підходи до невербальної комунікації, їхній вплив на життя, мімічні вияви емоцій, їхня соціальна роль, погляд як найбільш важливий i, практично, найвиразніший спосіб орієнтації в соціальному світі, невербальні голосові сигнали та їхнє значення, жести та порухи тіла, простір - усе це яскраво вербалізовано в співомовках Степана Руданського, органічно супроводжує репрезентацію живого мовлення українців.

Наголосимо також, що сьогодні надзвичайно необхідні наукові дослідження, що комплексно описують моделі невербальної комунікації ${ }^{10}$. Це потрібно передусім для вироблення відповідної теорії, адже сучасні праці з проблем невербальної комунікації мають більше науково-популярний, аніж науковий характер.

Актуальність дослідження визначаємо чинністю тенденції до інтегрування наукових напрямів, що сприяють більш детальному, якісному й об'єктивному вивченню проблеми. У межах цієї наукової розвідки зазначену тенденцію виявляємо на рівні синтезу лінгвістики з різними спеціальними течіями (соціо-, етно- та психолінгвістики, теорії комунікації, теорії невербальної комунікації та інших суміжних наук), з психологією, естетикою сприйняття.

Мета статті - визначити та описати національну специфіку невербального компонента, омовленого в художньо-естетичних текстах С. Руданського, що репрезентують „живе” мовлення українців. Наголосимо, що до цього часу зазначена проблема не була в полі зору науковців, зокрема й із залученням поетичного дискурсу С. Руданського.

„Живе мовлення” мотивоване комунікативною компетенцією, мовним чуттям і мовним смаком. Для більшості пересічних українців термін „співомовка”,

8 Л. В. Солощук, Взаємодія вербальних і невербальних компонентів комунікації ..., с. 16.

${ }^{9}$ Т. Космеда, Комунікативна компетенція I. Франка..., с. 138.

${ }^{10}$ См.: М. Коццолино, Невербальная коммуникация. Теории, функиии, язык и знак, пер. с итал., Харьков 2009. 
по суті, тотожний з віршованим анекдотом, тобто жанром, що репрезентує гумор. Саме на таке розуміння цього жанру скерував читачів й І. Франко в статті „До студій над С. Руданським”, де зазначав: „Найоригінальнішим і заразом найбільше народним явився Руданський у своїх „Співомовках”, в тих коротких епічних анекдотах, котрих сюжет звичайно взятий з уст народу...”11.

У „Словнику літературознавчих термінів Івана Франка” С. Пінчука і С. Регушевського його укладачі зазначають, що „співомовка - специфічно український жанр епічної поезії, запроваджений у літературу С. Руданським; коротке віршоване оповідання з гумористичним змістом, побудоване, як правило, на основі народного анекдоту"'12.

В. Ізер у праці „Гра тексту” зауважує, що найменшим ігровим простором тексту є „розщеплений знак”'13. Такі розщеплені знаки наявні в співомовках, моделюючись за допомогою певних стилістичних формул, девіацій, фігур і тропів, вербалізованих поетом.

Лінгвопоетичний аналіз передбачає вивчення словесно-художнього творчості, що, базуючись на всіх доступних для дослідника фонових знаннях, застосовує ці знання для того, щоб з'ясувати, як письменник актуалізує різні засоби мови для здійснення художнього задуму ${ }^{14}$.

Для опису невербальних компонентів комунікації автор використовує стилістичні мовні засоби — метафору, метафоричні епітети, порівняння, фразеологічні одиниці, що апелюють до знання мовця про навколишній світ i викликають відповідні асоціації, зокрема порівняння як стилістичний засіб $\epsilon$ найбільш уживаним у процесі відтворення релевантних для комунікації ознак невербального компонента, оскільки дає змогу викликати в уяві читача асоціації, що апелюють до концептуалізованого знання про довкілля. Це якнайкраще дає змогу розкрити художній образ і наближає творчість автора до фольклору й народнопісенної традиції, порівн.: Коли найдеш їx, / Милий синочку, / Ти склони себе, / Як билиночку. / Ти склони себе, / Як билиночку, / Простели себе, / Як рядниночку; Ярославни тихий голос / Незнакомий чує, / Зозулею ранорано / Бідная воркує ${ }^{15}$.

Просодичні та кінетичні невербальні елементи репрезентовано переважно метафорою, порівн.: Та ще й на п'ять сажнів в військо залітає. / Страх ворогам крики з горла вириває, / A з уст у забойців радість вилітає / I в очах веселих іскрами палає (с. 293).

Автор наслідує фольклорну традицію персоніфікації: I всі двері зачиняє, / Вуха затикає, / І сопілка грає-грає, / Ніби вимовляє (с. 247).

Уплетені в текст фразеологізми або їхня часткова модифікація ілюструють одну з ключових ознак ,живого” мовлення, порівн.: Але дармо лили воду / В peшето дюраве, / Не упало добре слово / На серце лукаве; Спом'янув тут бідний

${ }^{11}$ І. Франко, До студій над С. Руданським, [в:] Його ж, Зібр. творів, у 50 томах, Київ $1976-1986$, т. 28, c. 220.

${ }^{12}$ С. П. Пінчук, Є. С. Регушевський, Словник літературознавчих термінів Івана Франка, Київ 1966, с. 232.

${ }^{13}$ W. Iser, The Play of the text, [in:] „Languagens of the Unsayable”, The Play of Negativity in Literature and Literary Theory, Stanfort 1966, p. 329.

${ }^{14}$ В. Я. Задорнова, Лингвопоэтика. Слово в художественном тексте, [в:] Язык, сознание, коммуникация, отв. ред. В. В. Красных, А. И. Изотов, вып. 29, Москва 2005, с. 14.

${ }^{15}$ С. В. Руданський, Усі твори в одному томі, уклад. і авт. передмови Г. Латник, КиївІрпінь 2007, с. 279. - Далі подаємо поклики на це видання у тексті статті (після наведення прикладу вказуватимемо конкретну сторінку). 
дідич / Чорта і чортицฺю, / Плюнув з лиха, сів на бричку:/ „Рушай за границюю!' (с. 32); І гримнуло десять тисяч / Як грім серед літа: / „Веди, веди, куди хочеш, / Веди на край світа!”' (с. 157).

С. Руданський - талановитий репродуктор народного традиційного матеріалу й історичних фактів ${ }^{16}$. I. Франко наголошує на типажі образів поета, зауважуючи, що співомовка „дуже вдатно малює натуру українця - розважливу, трохи скептичну і з невеликим нахилом до фаталізму. Всяке добро має у нього й темний бік, а жодне лихо не буває без добра. При тім річ сама основана на таких чисто українських відносинах, як чумацтво, подорож у Крим, погана пригода в степу, що всякий відразу згодиться, що маємо тут діло $з$ анекдотом наскрізь національним, родимим, українським" 17.

У міжнаціональному спілкуванні колоритна зовнішність українців не лише привертає увагу, але й викликає гаму емоцій, що можуть „провокувати” відповідні закиди, порівн.: Питалися в козака: / „Що то за причина, / Що в вас гола голова, / А зверху чуприна?” / „А причина то така: / Як на війні загину — / Мене ангел понесе / В небо за чуприну!"(с. 155), або: Приӥхали запорожиі, / Короля вітають, / Король просить ӥх сідати, / Козаки сідають. / Сидять собі. В них жупани / Всі карамзинові, / I самі такі храбренні, / Вуса прездорові. / Задивились на ті вуса / Ляхи препогані. / „Що б їм, - кажуть, - дати їсти? / Даймо їм сметани!"(...),, А перше нам, запорожиям, / Щільник меду дайте”. / (...) Так ті вуса прездорові / Вгору завертіли (с. 54).

Текст репрезентує комунікативну компетентність українців у розв'язанні складної дипломатичної ситуації й уникненні конфліктного розвитку подій; в омовленні комунікативної ситуації автор використовує такі параметри, як дистанція (проксеміка), зовнішність героїв (фізіогноміка).

Яскраві описи зовнішності жінки наближають мовну творчість автора до фольклору й народнопісенної традиції, порівн.: Та й хвалиться не даремне, / Бо та Кочубівна / Була пишна і хороша, / Як та королівна. / Поглядає як голубка, / Ходить як лебідка, / А бігає, то літає, / Як та перепілка. / Як та піна, 3-під намиста / Груди виглядають, / Як ті тучі, чорні коси / Чоло вповивають. / Як та ружа садовая, / Ваблять ї̈ лиця, / I чорнії їі очі / Горять, як зірниця (с. 155). Авторський текст перегукується з народною піснею А хто хоче кумц̧ю знати, порівн.: Така красна яко рожа / Як тополя така гожа / А в рум'янциі такі сили / Що всі извіти погасили / Зуби якби перли чисті / Циці тлусті і паристі / А все тіло як сніг біло / Аж глянути на ню мило / Вона вся така як грушка / I м'якенька як пампушка / Зубки губки перлом чисті / Шия біла ще й в намисті / Уста як кораль червоні / Очки чорні і моторні / Кудри в ються за плечима / Чорні брови над очима ${ }^{18}$.

Зображення шлюбних взаємостосунків українців також нагадує народнопісенні образи, порівн.: Била жсінка мужика / Та й вигнала з хати. / <..> Здихнув бідний чоловік: / „Щасливий ти, брате, / Колись і я так співав, / Як був нежонатий!” (с. 81).

У тексті репрезентовано соціальний статус жінки в українській сім’ї як рівноправної чоловікові, навіть такої, що має більше повноважень, порівн. зокрема

${ }^{16}$ I. Франко, Нариси з історії украӥнсько-руської літератури до 1890 р., [в:] Його ж, Зібр. творів, у 50 томах, Київ 1976-1986, т. 41, с. 307.

${ }^{17}$ І. Франко, Студї̈ над. Ст. Руданським. „Ні зле, ні добре”, [в:] Його ж, Зібр. творів, у 50 томах, Київ 1976-1986, т. 28, с. 299.

${ }^{18}$ А хто хоче кумизю знати, [в:] Електронний pecypc: http://www.pisni.org.ua/songs/231573. html (доступ 21.05.2015). 
3 відомою українською народною піснею Як жінки чоловіків продавали ${ }^{19}:$ Ой, там на току, на базарі, / Жінки чоловіків продавали. / Як прийдеться до ладу, / Та й я свого поведу та й продам.

Разом із тим, автор наслідує головні принципи дошлюбного статусу жінки, що реалізовані в скромності, сором'язливості, порівн.: Стоїть козак коло груші, / Дівку підмовляє. / А дівчина, як калина, / Полум'ям палає (с. 60).

С. Руданський змальовує й образ селянина, що потрапляє в кумедне або безглузде становище, але, не переймаючись скрутною ситуацією, ніби сміється разом із читачем з себе: Несе, бідний, та й спіткнувся / У самім болоті. / I хильнулись нові ночви, / Затряслось свячене, / I в болото покотилось / Порося печене. / Глянув мужик на болото, / Посвистав до лиха, / Відвернувся, набік плюнув / Та й промовив стиха: / „Та свиня таки свинею! / Правду кажуть люди: / Святи ї̈, хрести ї̈ — / Все свинею буде!” (с. 69): репрезентовано акт автокомунікації, коли мовець, негативно апелюючи до абстрактного об’єкту, зберігає внутрішню психологічну рівновагу.

С. Руданський знайомить читача з особливостями національного харчування українців, вербалізуючи етнічні смакові уподобання (гастика) засобом омовлення різнопланових невербальних параметрів, порівн.: Я б по шию в салі спав (проксеміка), / В сало одягався (зовнішність), / Сало їв, на салі спав (гастика), / Салом укривався (с. 69).

Психологічне підгрунтя має фразеологічний паралелізм як такий, що відображає спільність характерних рис, паралельно зображуючи два явища з різних сфер життя ${ }^{20}$, зокрема психічного стану людини через зображення природної поведінки птаха широко відкривати й закривати очі: Сидить сова на камені, / Лупає очима; / Сидить гетьман Скоропада / Та й ниже плечима / Не згадає, не зміркує, / Що йому робити... (с. 161).

Семантика сталого виразу лупати очима відповідно до поведінки людини - блимати (блимнути, кліпати, кліпнути, лунати, лупнути і т. ін.) очима, що означає ,безтямно раз у раз розкривати і закривати очі від подиву, розгубленості, ніяковості і т. ін." 21 — корелює зі значенням конструкції низати плечима — „робити рухи плечима при здивуванні, нерозумінні, незнанні чого-небудь”22. Отже, застосований автором прийом сприяє увиразненню опису комунікативної поведінки персонажа.

Відомо, що численні характеристики голосу людини створюють його образ, сприяють розпізнанню його станів, виявленню психічної індивідуальності. Основне навантаження в процесі сприйняття голосових змін людиною лягає на акустичну систему комунікації. Просодика - сукупність таких ритмікоінтонаційних властивостей мовлення, як висота, тривалість, гучність, тембр голосового тону.

Омовлюючи просодичні невербальні елементи, С. Руданський намагається використовувати ,доповнювальний” контекст для змалювання параметральних ознак голосу: I живенько за поріг, / Крикнув наокола: / Бартку! Бартку! ходзь-но ходзьі... / Цебе біскуп вола. / А той йому з-за хліва / Голосом прегрубим: / - А облізал би изе пес / Враз з твоім біскупем! (с. 107).

19 Як жінки чоловіків продавали, [в:] Електронний ресурс: http://www.pisni.org.ua/songs/ 5150807.html (доступ 17.07.2015).

20 Паралелізм, [в:] Електронний ресурс: https://uk.wikipedia.org/wiki/Паралелізм (доступ 4.07.2015).

${ }^{21}$ Словник української мови, в 11 томах, редкол. І. К. Білодід та ін., Київ 1974, т. 5, с. 665.

${ }^{22}$ Там само, с. 410. 
Для опису параметрів голосу іноді автор використовує лексеми кричить, репетує, напр.: Верещить nin, репетує, / Кричить молодиия, / Соломняник скаче, скаче / I з гори валиться (с. 233).

Для вербалізації просодичних елементів поет залучає метафори й фразеологізми: Ярославни тихий голос / Незнакомий чує, / Зозулею рано-рано / Бідная воркує... (с. 279); I дівчата на Дунаї / Співають і в'ються, / І голоси через море / До Києва ллються (с. 281). Такий звуковий діапазон мотивований експресивністю українського національного характеру, схильністю виявляти почуття на емоційно-мовленнєвому рівні, кордоцентризмом (від лат. „кордос” - серце) - розуміння дійсності не стільки мисленням („головою”), скільки „серцем” - емоціями, почуттями, внутрішнім, „душею”, що грунтується на ототожненні істинної сутності людини - серця 3 духовною реальністю ${ }^{23}$.

Екстралінгвальна система репрезентована наявністю в мові пауз, різного роду психофізіологічних проявів людини: плач, камель, сміх, зітхання, шепіт тощо, порівн.: А полковник реготить, / Аж мало не ляже: / „Куда єго ти вєдьош?” / „На вадапой!” — каже (с. 97): тут вербалізовано своєрідність процесу сміху (реготу) із додатковою характеристикою (аж мало не ляже), що вказує на його інтенсивність.

Для вербалізації кашлю С. Руданський омовлює звуконаслідувальні мовні одниниці (напр., „кахи”, „кахи”), дублюючи їх, моделює живу розмовну ситуацію, порівн.: А жидок — „кахи”, „кахи”! / Кашляє в макітру (с. 116); або: Кінчилося діло, / Аж Микита із кутка: „Кахи!” собі сміло (с. 84).

До арсеналу екстралінгвальних явищ С. Руданський включає також шепіm як особливе акустичне явище мовлення в стані молитви, порівн.: Баби шепчутьь, дяк ворожсить, / Воду nin святить... (с. 35), що водночас може набувати певної конотації, зокрема шепіт як інструмент замовляння, ворожіння, порівн.: Як тая цариия, / Що ї̈ зашептала / На сон чарівниия (с. 12).

Репрезентацію „живого” мовлення в тестах С. Руданського простежуємо на прикладах авторських ремарок щодо інтонаційного втілення реплік його героїв, порівн.: Тогді гетьман Полуботка / К серию пригортає. / „Полуботку, Полуботку", - / 3 дивом промовляе. (с. 164); І узяв він тії річі, / К серию пригортає, / Заливається сльозами, / Стиха промовляє... (с. 226). Співвідношення модуляцій голосу з комунікативною ситуацією також забезпечує „доповнювальний” контекст, у якому описано відповідну ситуацію.

Гаптична система, як відомо, репрезентує мова дотиків і тактильної комунікації. У поетичному мовленні С. Руданського гаптичні невербальні засоби омовлені переважно лексемами пригорнути, пригнутися (у значенні „притулитися”, „пригорнутися”), обіймати та їх словоформами: А брати молодші, / Сестра моя рідна - / До кого пригнеться / Голівка їх бідна? (с. 11) - невербальний параметр набуває символічного значення: пригорнутися означає „знайти прихист, оборону”; Хто вінок розв'яже, / Той косу зав'яже, / Той дівча пригорне, / Щиру правду скаже (с. 16) - вербалізовано шлюбний ритуал заручин, що характерний для української народної культури: Но ияарівна знов мовчала, / Не одповідала, / Лиш обняла ще тісніше / I поцілувала. (с. 245) - омовлено відповідну комунікативну дію; А воно Енея тільки обійняло, на шиї повисло, / I, до свого батька несправжнього ласку великую вдавщи, / Іде до ирариці. А та і очима, і иілою груддю, / Тулиться до його, к лону пригортає (с. 301)

${ }_{23}$ Кордоиентризм, [в:] Електронний ресурс: https://uk.wikipedia.org/wiki/кордоцентризм (доступ 11.0.2015). 
— „доповнювальний” контекст уточнює характер комунікативної дії, колоритно забарвлюючи сприйняття описаної в тексті комунікативної ситуації.

Через омовлення невербальних параметрів комунікації автор змальовує ситуації, що репрезентують етнічні взаємостосунки українців 3 іншими народами — „москалями”, „жидами”, „шляхтичами”, циганами тощо, порівн.: Реготять дурні кацุапи, / А він тілько сплюне / Та й до другої крамниці, / Багатшої, суне. / В найбагатшї крамниці / Два купиі сиділо, / I туди чумак заходить / 3 мазницею сміло: / „Добридень вам, добрі люди!” — / Та й зачав питати, / Чи нема у них принаймні / Дьогтю де продати. / „Нєту, нєту! ”-купці кажуть, / Та й, шельми, сміються: — / „З Зєсь нє дьоготь - толькі дурні / Адні продаються!"” (с. 34) — невербальна складова підсилена словесною, що викликає негативну оцінку комунікативної ситуації: кацапи дурні, шельми, реготять, сміються, натомість чумак заходить сміло, суне, не зважає на зверхнє ставлення: А він тілько сплюне; або: Підійнявся вражий циган / Та як зарегоче: / „Мені того й бракувало..../ Добраніч, панотче!" (с. 49), Іде цииан вечеряти / Та слину ковтає... (с. 48) - вербалізовано комунікативні стратегії хитрості, що є стереотиповою ознакою циганського етносу.

Гумористично змальовує С. Руданський деякі особливості кінетичної поведінки „рабинів” і „жидів”, порівн.: На підсінні в малій хаті / Сидить старий хусит, / Вопівночі над талмудом / Бородою трусить (с. 40); Розхитався жид на сабаш, / Бородою має... / Не своїми голосами / „Тефиліт” читає... (с. 44); Чи звелить він козакові / Мовити з собою... / Рабин тільки подивився, / Махнув бородою ... <..> Кивнув рабин головою, / Махнув бородою; / Показує йому вгору /Правою рукою!.. (с. 51).

Навіть жиденята й циганчата в нього „мають”, але вже голівками: Cuдить мале жиденя, / Головкою має, / А жидівка молода / Тілько розважає (с. 65); Стоӥть собі жиденятко, / Головкою має; / Коло нього сидить рабин / Та й його numae (с. 65).

Адекватне декодування засобів невербальної комунікації залежить не лише від контексту їхнього омовлення, але й від фонових знань, їхньої специфіки в контексті комунікативної ситуації, порівн.: 1) Затряслися в злості усі його кості, / І махнув рукою, туром реве в злості: / „Горе тим пташенятам, де змія ночує, / Горе і тим мужам, де жінка панує!" (с. 298) - репрезентовано жест погрози, демонстрації сили; 2) А вони давай всі разом / Пазури мачати. / I мачають, і махають / Обома руками (с. 184) - зображено динаміку ритуальних рухів, мотивованих певною символічною поведінкою; 3) I махнув бог свойм слугам / Правою рукою / I говорить: „Будьте, діти, / Вічне ви зо мною” (с. 182); I махнув Карло рукою, / Мигнув до Мазепи, / I все військо зворушилось, / Полетіло в степи (с. 160) - проілюстровано владний жест-сигнал на виконання певної дії; 4) А полковник із вікна / Махає рукою: / „Ну, астав єго, астав! / Я $і$ сам напою” (с. 97) - омовлено жест-заборону щодо відповідної інтенції.

Актуалізацію невербальних параметрів простежуємо вже в сильних текстових позиціях, якими є заголовки співомовок, напр.: „Чи голосна церква?”, „Бородатий хусит”, „А не халасуй!”, „Чуприна”, „Голодний жид”, „Довгий зуб”, „Глухий і губатий”, „Что смотріш?”, „Ов!”, „Малчі!”, „Сміх” та ін.

Таким чином, сприйняття паралінгвального дискурсу загалом забезпечено дихотомією мовної й комунікативної компетенції мовця й реципієнта. Невербальний супровід мовлення — це процес, що залишається без належної уваги, однак він суттєво підтримує взаємодію людей. Невербаліка доступна для 
сприйняття й розуміння інших людей, але вона містить і приховані, навіть загадкові чинники, які потрібно ретельно вивчати й описувати.

Отже, невербальний складник, як і вербальний, відіграє велику роль у поетичному мовленні С. Руданського. Невербаліка збагачує поетичне мовлення, уводить нові контексти, заміщує або доповнює вже існуючі, дає додаткові можливості авторові передати певне смислове та психоемоційне наповнення поетичного дискурсу.

Поетична творчість С. Руданського грунтується на національних особливостях спілкування, відображає національну специфіку українського побуту, колорит української зовнішності й характеру.

Народнопісенна основа поезії С. Руданського репрезентує етнічну манеру мовлення, комунікативні форми спілкування, традиційні мовні формули.

С. Руданський широко застосовує лексичний, фразеологічний, стилістичний ресурс мови, що надає художньо-поетичним текстам нового естетичного наповнення, відзначає ідіостиль автора як стиль елітної мовної особистості ${ }^{24}$.

В українській лексикографії, на жаль, на сьогодні відсутній словник опису невербальних комунікативних засобів. Цей науковий опус доводить, що омовлення невербаліки українців у живому дискурсі XIX ст., репрезентоване Степаном Руданським, може стати гарним ілюстративним матеріалом для відповідного словника невербальних засобів української мови - у цьому вбачаємо перспективу наукової студії.

${ }^{24}$ Див.: Т. А. Космеда Ego i Alter Ego Tapaca Шевченка в комунікативному просторі щяоденникового дискурсу, Дрогобич 2012. 